\title{
COMPETITION, DIVERSIFICATION, AND STABILITY IN THE INDONESIAN BANKING SYSTEM
}

\author{
Mudeer Ahmed Khattak*, Baharom Abdul Hamid**, Muhammad Umar Islam*** \\ and Mohsin Ali**** \\ *Faculty of Business Administration, Iqra University Islamabad, Pakistan. \\ Email: mudeerkhattak@gmail.com \\ ${ }^{* *}$ International Center for Education in Islamic Finance (INCEIF), Lorong Universiti, Kuala Lumpur, \\ Malaysia. Email: baharom@inceif.org \\ ***School of Accounting and Finance, Asia Pacific University of Technology and Innovation, Malaysia. \\ Email: umar.islam@staffemail.apu.edu.my \\ ****Corresponding author. Taylor's Business School, Taylor's University, Malaysia. \\ Email: mohsin.ali@taylors.edu.my
}

\begin{abstract}
We examine the impact of competition and portfolio diversification on banking stability for conventional and Islamic banks in Indonesia. We find that the Islamic banking sector is less stable, when compared to the conventional banking sector. Competition in the banking sector reduces stability, while diversification enhances it. We find that competition negatively impacts the Islamic banks, but diversification has no impact on these banks. An interesting finding is that competition and diversification complement each other in enhancing the stability of the Indonesian banking sector. These findings carry an important policy implication for the banking sector of Indonesia.
\end{abstract}

Keywords: Bank competition; Diversification; Stability; Dual Banking; Indonesia.

JEL classifications: G21; G33; G38.

Article history:

Received : October 03, 2020

Revised : December 20, 2020

Accepted : January 04, 2021

Available online : January 31, 2021

https://doi.org/10.21098/bemp.v24i0.1481 


\section{INTRODUCTION}

As competition among banks increases, they tend to shift their focus towards nontraditional activities ${ }^{1}$ (Pennathur, Subrahmanyam, and Vishwasrao, 2012) to makeup for drops in profits, by diversifying their sources of revenue. Hence, banks' non-traditional activities may play a role in the relationship between competition and bank stability. The interrelationship among competition, stability, and diversification became more important after the global financial crisis of 2008/09 (Pawlowska, 2015). Understanding the role of competition and diversification in bank stability has become even more important in recent times, given the severe disruptions of global financial markets caused by the COVID-19 pandemic. $^{2}$ In the literature, many studies have targeted US and European countries when examining the relationship among competition, stability, and diversification and found mixed results (Sanya and Wolfe, 2011, Schaeck and Cihak, 2014, Fiordelisi and Mare, 2014).

As far as Asian countries are concerned, the relationship among competition, stability, and diversification has been rather under explored. Indonesia is one of the few economies, which successfully survived the global financial crisis. Indonesia's economy had a quick recovery with fewer bank failures (Agnes Isnawangsih, Klyuev, and Longmei Zhang, 2013), which provided evidence of better preparedness after the 1997/98 Asian financial crisis. ${ }^{3}$ This has drawn interest among researchers to investigate the sources of Indonesia's resilience to global financial crisis.

Another interesting feature of this country, which has the largest Muslim population in the world, is the prevalence of a dual banking system i.e. Islamic banking and conventional banking systems. ${ }^{4}$ In 2008, Indonesia introduced a separate governing act for Islamic banking (Ali and Khattak, 2020) . Research has suggested that the development of Islamic banking has added to Indonesia's economic development (see Zahra, Ascarya and Huda, 2018; Juhro et al., 2020). This makes Indonesia's banking sector very attractive to study because, as noted by Azmi et al. (2019), the rise in competition in a dual banking environment is expected to affect conventional banks more as their customers may choose to shift to Islamic banks, whereas the customers of Islamic banks may not switch to non-shariah compliant banks. Researchers have studied the regulatory and risk management systems of Indonesia but have seldom focused on the impact of market competition and non-traditional sources of revenues on banks.

1 Non-traditional activities include fee-based services like securities brokerage and selling insurance and asset-based activities, such as investment banking, venture capital and securitization of assets (DeYoung and Torna, 2013).

2 Several studies, such as Appiah-Otoo (2020), Devpura (2020), Devpura and Narayan (2020), Fang \& Zhang (2021), Hoang \& Syed (2021), Gil-Alana \& Monge (2020), Gil-Alana \& Claudio-Quiroga (2020), Huang \& Zheng (2020), Iyke (2020a, b), Iyke and Ho (2021), Narayan (2020a, b, c), Phan and Narayan (2020), Prabheesh et al. (2020), Wang \& Su (2021), Yang \& Deng (2021), Salisu \& Adediran (2020), Salisu \& Sikiru (2020), Sha \& Sharma (2020), Sharma \& Sha (2020), and Sharma (2020), show that the COVID-19 pandemic has disrupted global economies and financial markets.

3 Juhro and Iyke (2019) note that Indonesia is one of the severely affected countries by the Asian financial crisis.

4 Juhro et al. (2020) highlight some of the appealing features of an Islamic financial system. 
To fill this gap, this study examines the relationship among bank stability, competition, and diversification. Many studies have studied the impact of competition on risk or diversification on risk (Agnes Isnawangsih et al., 2013), but there are relatively fewer studies that have studied the interrelationship among these variables, especially, in developing countries like Indonesia. Azmi et al. (2019), in their study on 22 dual banking economies, found no difference with regards to the impact of diversification and competition on the stability of Islamic and conventional banks. In this study, we suggest that the link between stability and competition (diversification) may be contingent on the level of banks' diversification (competition) strategy. We hypothesize that the benefits from diversification may bring a difference in the impact of competition on stability. We further hypothesize that the pressure of increasing competition may push banks to move towards income diversification strategies, which may affect bank stability. Banks tend to opt for different income sources to hedge their risk (Froot and Stein, 1998) and to enhance profitability and efficiency (Landskroner, Ruthenberg, and Zaken, 2005).

Our research contributes to the growing literature on competition-stability and diversification-stability links with special focus on dual banking (Azmi, Ali, Arshad, and Rizvi, 2019; Kabir and Worthington 2017). In this study, we attempt to address five objectives. Specifically, we examine: (i) the impact of competition on bank stability; (ii) the impact of diversification on bank stability; (iii) whether the impact of competition and diversification on bank stability is different for Islamic banks; (iv) the moderating role of competition and diversification on the competition-bank stability and diversification-bank stability relationship for the overall sample; (v) whether there is any difference in the moderating role of competition and diversification on bank stability for Islamic banks and conventional banks ${ }^{5}$.

To address our objectives, we first dig into the measurement of stability and competition. We measure stability using a widely used Z-score (see Phan et al., 2020). We measure competition using a market power measure, the Lerner index, which is an inverse measure of competition (Azmi et al., 2019). For more robust analysis, and to control for possible issues of unobserved heterogeneity, endogeneity, and autocorrelation, we use the system generalized method of moments (GMM). Our study reveals that Islamic banks are less stable as compared to conventional banks. As we probe more, we find that competition among Indonesian banks appears to reduce their stability, whereas portfolio diversification seems enhance stability. We find competition harms Islamic banks' stability, whereas we do not find any impact of diversification. We further find a negative moderating role of competition and diversification in bank stability, which suggests that competition and diversification can complement each other in enhancing the level of stability in the overall Indonesian banking sector.

The remainder of the paper proceeds as follows. Section 2 presents the literature review. In section 3 presents the data, discusses how the variables are

This study conducts a cross check on the moderating role of competition and diversification between competition-stability and diversification-stability relationship, respectively. This is explained in detail in section IV B. 
calculated, and briefly describes the methodology. Section 4 presents the empirical results. Section 5 provides the conclusion and policy implications.

\section{LITERATURE REVIEW}

The studies on competition and bank stability show contrasting views. Primarily, there are two main theories concerning the impact of competition, namely the competition-stability and the competition-fragility theories. The competitionfragility theory argues that, as the new players enter the industry, the market share of banks and bank profitability decreases, and in turn pushing banks to indulge in risky business activities to enhance their profitability (Allen and Gale, 2004; Hellmann, Murdock, and Stiglitz, 2000). This theory has been tested and supported by Fungáčová and Weill (2013) and Jiménez, Lopez, and Saurina (2013). On the other hand, the competition-stability theory suggests that, as the market power increases, bank risk also increases. Stiglitz and Weiss (1981) showed that normally the loan rates are higher in lesser competitive bank markets, which force borrowers to venture into riskier projects to increase their profit margin (see Leroy and Lucotte, 2017). This theory has been verified by Fiordelisi and Mare (2014), Pawlowska (2016) and Schaeck and Cihak (2014).

The impact of competition on stability in dual banking economies like Indonesia is rarely examined in the literature. Azmi, Ali, Arshad, and Rizvi (2019) and Kabir and Worthington (2017) tried to fill this gap by employing panel data from different dual banking economies. They suggest the presence of competitionfragility hypothesis for both Islamic and conventional banks. But these studies were more generic as they look at several economies at once. Rizvi et al. (2019) studied the impact of Islamic banks on the Indonesian banking sector, but their focus was not directly on competition and income diversification. Ali et al., (2020) studied East Asian dual banking countries and found an increase in competition due to Islamic banks increases the stability of the banking industry, although it does not impact profitability.

Another strand of literature discusses the diversification strategies that banks adopt in response to a high level of competition (Pennathur, Subrahmanyam, and Vishwasrao, 2012). Diversification helps banks to enhance/maintain their market share (Goddard, Molyneux, and Wilson, 2009). Despite the number of studies presenting the benefits of income diversification, Deyoung and Roland (2001) have argued that diversification increases bank risk. They suggest that diversification increases fixed costs and earnings volatility. They put forth three explanations for the increase in risk due to the income diversification strategies of banks. Firstly, switching to different banks is easier in non-traditional activities because of the shorter nature of engagement. This enhances the bank's income volatility. Secondly, banks need to invest in terms of fixed cost, if they want to indulge in non-traditional activities, as they require different technology and talent. Lastly, regulators do not set any capital requirements on these non-traditional activities. This can also decrease bank stability. Several studies, including Mercieca, Schaeck, and Wolfe (2007) and Stiroh and Rumble (2006), do not find any association between income diversification and bank stability. On the other hand, Baele, De 
Jonghe, and Vander Vennet (2007) and Landskroner, Ruthenberg, and Zaken (2005) show a positive association between diversification strategies and bank stability.

The aforementioned studies have predominantly focused on the US and European countries. As far as developing Asian economies are concerned, very limited studies exists on the relationship between non-traditional activities and bank stability. Rizvi, Narayan, Sakti, and Syarifuddin (2019), recently studied the relationship indirectly. There are also very few studies on individual dual banking economies, except for Abdullah et al. (2011), who focused on Malaysia and Karakaya and Er (2012), who focused on Turkey. Even these studies have only focused on the impact of diversification on bank performance.

In this study, we do not only look at the direct relationship between competition and stability, and diversification and competition, but we also examine the interlinkages among these three variables, by interacting competition and diversification.

\section{DATA, VARIABLE SPECIFICATION, AND METHODOLOGY}

The study relies on banking data sourced from the Fitch Connect database, which provides detailed information on banking financial statements, globally. The country-level variables are sourced from World Development Indicators database of the World bank. To have a more reliable dataset, we use only consolidated data to avoid any double-counting, in addition to limiting the dataset to at least 3 years of observations on banks. The final dataset consists of an unbalanced annual panel data of 123 banks (including 13 Islamic and 110 conventional banks) in Indonesia from 2007 to 2018. The dataset starts from 2007 as that was the time when the Islamic banking act was approved in Indonesia. Additionally, following Azmi et al. (2019) and Cihák and Hesse (2010) the sample is further split into large and small banks. Banks with total assets lower than 1 billion are classified as small and big otherwise. Upon classification, the dataset is split into 66 large banks and 79 small banks.

\section{A. Model Development and Methodology}

Considering the nature of this research, employing traditional panel estimators for regression analysis like pooled ordinary least square (POLS), fixed effects (FE), and random effects (RE) estimators might not be suitable. The issues like unobserved heterogeneity, endogeneity, and correlation might result in erratic results and conclusions. Besides this, the dependent variable might dynamic or persistent, which is a very crucial factor to consider in economics and finance studies. To control for potential persistency of the dependent variable, we include a lag of the dependent variable in the model. The inclusion of the lagged dependent variable (that is zscore $_{t-1}$ ) in the model makes the POLS, FE, RE estimators inappropriate for our analysis. Instrumental variable estimators are appropriate in this setting; however, finding instruments that are highly correlated with the lagged dependent variable but uncorrelated with the error term is difficult. Arellano and Bond (1991) suggested a consistent GMM estimator to address all these issues. The so-called difference GMM (DGMM) estimator uses the lagged values of exogenous variables 
as instruments. However, Arellano and Bover (1995) and Blundell and Bond (1998) criticize the estimator and argue that, if the instruments used in the estimation are weak, the difference GMM might be ineffective. With this criticism, they proposed the system GMM estimator, which uses the lagged level and the lagged differences of the variables as instruments.

Roodman (2009) suggests that the difference and system GMM estimators can address the issues of unobserved heterogeneity, endogeneity, correlation concerns, and persistence. Furthermore, the system GMM estimator is most suitable when $T$ is small, $N$ is large, and when the dependent variable is dynamic (i.e. persistent). In addition, the system GMM estimator is suitable when control variables might correlate with the error term (i.e. control variables are not exogenous) and when there is heteroscedasticity in the data, which are more probable in bank-level data. The two-step system GMM estimator refines the quality of estimation, while controlling for endogeneity, serial correlation, and heteroscedasticity issues (Roodman, 2009).

We use the system GMM estimator to examine the impact of bank competition and diversification on bank stability and to explore any moderating roles of competition and diversification in shaping the relationship of either variable with stability. Along with one period-lag of zscore, we applied different diagnostic tests to address possible issues of autocorrelation and over-identification of instruments, using the Hansen test (Hansen-PV) and the autocorrelation tests (AR1, AR2). Using Roodman (2009)'s xtabond2 command, the system GMM estimator is based on forwarding orthogonal deviation instead of first differencing because our panel data unbalanced. The system GMM estimator is more suitable in this case because the difference GMM estimator magnifies gaps in unbalanced panels (Iyke, 2017). While estimating the models, the lagged dependent variable is treated as endogenous, the bank-specific variables are treated as potentially endogenous or predetermined and the country-specific variables as treated as strictly exogenous variables. To examine the impact of competition and diversification on financial stability zscore separately, we estimate the following models:

$$
\begin{aligned}
\text { zscore }_{j t}= & \beta_{0}+\beta_{1} \text { zscore }_{j t-1}+\beta_{2} \text { Lerner }_{j t}+\beta_{3} \text { Diver }_{j t}+\beta_{4} B S_{j t}+ \\
& \beta_{5} \text { Islamic }_{j t}+\beta_{6} \text { Mac } t+\varepsilon_{j t}
\end{aligned}
$$

where, $t$ and $j$ denote year and bank. zscore is bank stability indicator; $z s c o r e j_{t-1}$ is the one-period lag of bank stability. Lerner denotes the inverse measure of competition measured by banks' market power. Diver denotes the income diversification. $B S$ denotes the bank-specific characteristics that might affect the stability of banks. Islamic indicates the dummy variable for Islamic banks, which takes the value of 1 if the bank is Islamic and 0 otherwise. Mac indicates macroeconomic variables, which include the banking market structure $(H H I)$ in the country, Gross Domestic Product (GDP) growth rate and inflation rate, is used to control for the countryspecific heterogeneity. $\varepsilon$ indicates residuals.

The limited number of Islamic banks in the dataset does not allow us to conduct a split sample analysis. Therefore, we introduce dummy interaction terms in the following models to differentiate the impact of diversification and competition 
on Islamic bank stability from conventional bank stability. The significance of the interaction terms would indicate the difference in the impact of diversification and competition on Islamic banks vs conventional banks in Indonesia. To do this, we estimate the following modified model:

$$
\begin{aligned}
\text { zscore }_{j t}= & \beta_{0}+\beta_{1} \text { lnZ }_{j t-1}+\beta_{2} \text { Lerner }_{j t}+\beta_{3} \text { Diver }_{j t}+\beta_{4} \text { Lerner }_{j t} * \text { Islamic }_{j t} \\
& +\beta_{5} \text { Diver }_{j t} * \text { Islamic }_{j t}+\beta_{6} B S_{j t}+\beta_{7} \text { Islamic }_{j t}+\beta_{8} \text { Mac }_{t}+\varepsilon_{j t}
\end{aligned}
$$

To explore the moderating role of competition and diversification in shaping the relationship of either variable with stability, we modified Equation (1) by including of an interaction term between the Lerner index and diversification Lerner*Diver. The significance of the interaction term would indicate any possible moderating role. The modified model is as follows:

$$
\begin{aligned}
\text { zscore }_{j t}= & \beta_{0}+\beta_{1} \ln Z_{j t-1}+\beta_{2} \text { Lerner }_{j t}+\beta_{3} \text { Diver }_{j t}+\beta_{4} \text { Lerner }_{j t} * \text { Diver }_{j t} \\
& +\beta_{5} \text { BS } S_{j t}+\beta_{6} \text { Islamic }_{j t}+\beta_{7} \text { Mac }_{t}+\varepsilon_{j t}
\end{aligned}
$$

We further examine whether the moderating role of competition and diversification is different for Islamic banks. To do this, we modify Equation (3) using a 3-way interaction term, Lerner ${ }^{*}$ Diversification*Islamic. This interaction term consists of two continuous variables (Lerner index and diversification) and one categorical variable, Islamic dummy. The significance of this simple yet complex interaction term would indicate the difference in the moderating role of competition in the relationship between diversification and stability and the moderating role of diversification in the relationship between competition and stability. The modified model is given as follows:

$$
\begin{aligned}
\text { zscore }_{j t}= & \beta_{0}+\beta_{1} \text { lnZ }_{j t-1}+\beta_{2} \text { Lerner }_{j t}+\beta_{3} \text { Diver }_{j t}+\beta_{4} \text { Lerner }_{j t} \\
& * \text { Islamic }_{j t}+\beta_{5} \text { Diver }_{j t} * \text { Islamic }_{j t}+\beta_{6} \text { Lerner }_{j t} * \text { Diver }_{j t} \\
& +\beta_{7} \text { Lerner }_{j t} * \text { Diversification }_{j t} * \text { Islamic }_{j t}+\beta_{8} \text { BS }_{j t} \\
& +\beta_{9} \text { Islamic }_{j t}+\beta_{10} \text { Mac }_{t}+\varepsilon_{j t}
\end{aligned}
$$

\section{B. Dependent Variables}

To measure bank stability, we use the Z-score, which is widely used in the literature (Albaity, Mallek, and Noman, 2019; Čihák and Hesse, 2010; Demirgüç-Kunt and Detragiache, 2009; Laeven and Levine, 2009; Phan et al., 2020). This measure shows the distance from insolvancy (Beck, De Jonghe, and Schepens, 2013; Goetz, 2017; Leroy and Lucotte, 2017; Nurul and Worthington, 2015). Demirgüç-Kunt and Detragiache (2009) referred to Z-score as an upgrade of the indicators used in the literature, such as accounting ratios like NPL, interest-margin, and capitaladequacy. The higher the Z-score, the lessor the risk, and therefore the greater the stability. We use a three-year rolling window to estimate standard deviation of return on assets, which is generally sufficient to allow for variation in the Z-score. To avoid the skewness in the Z-score, we use its natural logarithm. We calculate Z-score as follows: 


$$
\text { Zscore }=\frac{\text { Equity ratio }+ \text { ROA }}{S D \text { of } R O A}
$$

where Zscore denotes Z-score, Equity ratio indicates the ratio of equity to total assets, $R O A$ denotes that return on assets. SD of ROA is the 3-year rolling window standard deviation of return on assets.

\section{Independent variables}

Competition is considered one of the main determinants of bank risk, due to its impact on banks' earnings (Adjei-Frimpong, Gan, and Hu, 2016; Schaeck, Cihak, and Wolfe, 2009; Ariss, 2010). It is almost impossible to measure bank competition; therefore, the literature proposes the use of bank market power instead, where lower market power implies greater competition and vice versa (Azmi et al., 2019). This research employs a bank-level measure of market power, the Lerner index, which is an inverse measure of market competition. This is unlike Rizvi, Narayan, Sakti, and Syarifuddin (2019), who used an industry level concentration measure as a proxy for bank competition. The Lerner index is defined as the margin that a bank can set above its cost. It combines the price and the marginal costs to estimate the bank's power in the market. Unlike the H-Statistic, Boone Indicator, and Herfindahl Hirschman Index, the Lerner index can be estimated at each point in time and is considered as short-term equilibrium measure, which gives the Lerner index a special position. The Lerner index is given as follows:

$$
\text { Lerner }_{j t}=\frac{\left(P_{j t}-M C_{j t}\right)}{P_{j t}}
$$

$P_{j t}$ denotes the price, whereas $M C_{j t}$ denotes the marginal cost of bank $j$, in year $t .^{6}$

Diversification is measured as the ratio of total non-interest income to total income. This is used to examine the impact portfolio diversification on bank stability and it differs across banks according to their investment strategies. Researchers are inconclusive about the relationship between diversification and bank stability. While some found a positive relationship between income diversification and stability and concluded that more diversified banks are better stable (Amidu and Wolfe, 2013a; Liu et al. 2012), others found a negative relationship between these variables. For example, Deyoung and Roland, (2001) found that higher diversification brings more risk. Hence, based on the literature, the sign of this variable is uncertain.

To control bank-specific characteristics that might impact bank stability, we use bank size measured by the natural logarithm of total assets (TA), the equity ratio also called capitalization ratio (EQTA), bank loan ratio (GLTA) and the Cost to Income Ratio (CIR). It is argued that banks with bigger sizes and higher equity

\footnotetext{
6 For detailed explanation on Lerner index, see Ariss (2010), Boateng, Asongu, Akamavi, and Tchamyou (2018), Kabir and Worthington (2017), Kouki and Al-Nasser (2017), and Nguyen, Perera, and Skully (2016).
} 
ratios have higher financial performance and are better stable (Liu et al., 2012). Loan ratio is used to control the credit exposure of banks, as they might have significant effects on the banks. Furthermore, it is argued that banks that have higher loan ratios are likely to have poor performance and are risky and unstable stable (Alaeddin, Khattak, and Abojeib, 2019). Ideally, a higher loan ratio should increase the level of riskiness; however, it will not be surprising if this research finds a positive relationship between loan ratio and stability measure. This might be due to the reason that banks with higher loan ratios might be able to accumulate higher gains, hence, are more stable. For instance, Mercieca, Schaeck, and Wolfe (2007) found that banks with higher lending activities tend to perform better and are better stable, but at the cost of higher risk. The cost to income ratio is measured as the ratio of operating costs to income, where cost-efficient banks are expected to be better stable. This ratio shows the costs of running the bank, the major element of which is staff salaries and benefits.

Following the studies of Boyd, Nicolò, and Jalal (2006), Fungáčová and Weill (2013) and IJtsma, Spierdijk, and Shaffer, (2017), the concentration-stability/ fragility view further motivates us to control for market structure and to include market structure $(H H I)$ as a control variable in the model. $H H I$ is defined as the sum of the squares of the market shares of the banks in the market (Bikker and Haaf, 2002). ${ }^{7}$ We argue that if the market is concentrated, it does not necessarily mean that there is no competition and that concentration and competition can coexist in the market.

To control for the differences in the macroeconomic environment, we include GDP growth rate and inflation rate in the model. It is argued that the global financial crisis causes the banking market to undergo reform and structural changes, which are believed to affect banks' financial performance (Abuzayed, AlFayoumi, and Molyneux, 2018; Fu et al., 2014). Therefore, we introduce a crisis dummy in the model, which has a value of 1 for the year 2008-09 and 0 otherwise. Table 1 presents the variables, their definitions, expected signs, and their sources.

\section{EMPIRICAL RESULTS AND DISCUSSION}

Table 2 provides the descriptive statistics of the dataset used in the analysis. For the full sample, the mean for zscore, is 3.18 with a deviation of 1.01. This shows that Islamic banks have lower stability as compared to conventional banks. The mean value for Lerner index is 0.35 , which indicates relatively moderate level of competition with variability of 0.17 . Islamic banks appear to be more competitive than conventional banks. Bank diversification has a mean of 0.18 with a standard deviation of 0.19 . Islamic banks seem to be better diversified than their conventional counterparts. Table 3 presents the pairwise correlation coefficients for all the variables using Pearson's correlation test. The correlation coefficients reveal a weak relationship between the independent variables; therefore, we do not observe the existence of multicollinearity.

$7 \mathrm{HHI}$ is estimated as: $\mathrm{HHI}=2 \sum_{j=1}^{n}\left(M S_{n}\right)^{2}$, Where $j$ is the number of banks in the country in a year. 
Table 1.

\section{Definitions and Sources of the Variables}

This table provides the definitions and sources of the variables used in this study. + denotes positive relationship, denotes negative relationship, and + - - denotes mixed findings. FCDB and WDI denote, Fitch Connect Database and World Development Indicators of the World Bank, respectively.

\begin{tabular}{|c|c|c|c|c|}
\hline Variable & Symbol & Definition & $\begin{array}{l}\text { Expected } \\
\text { Sign }\end{array}$ & Source \\
\hline \multicolumn{5}{|c|}{ Panel A: Dependent Variables } \\
\hline Stability & zscore & $\begin{array}{c}\text { The ratio of the sum of equity } \\
\text { ratio to total assets and ROA } \\
\text { to the standard deviation of } \\
\text { ROA }\end{array}$ & & $\begin{array}{c}\text { Authors' calculation } \\
\text { FCDB }\end{array}$ \\
\hline \multicolumn{5}{|c|}{ Panel B: Core variables } \\
\hline Competition & Lerner & $\begin{array}{l}\text { Market power, used as } \\
\text { an inverse measure of } \\
\text { competition }\end{array}$ & + & $\begin{array}{c}\text { Authors' estimation } \\
\text { FCDB }\end{array}$ \\
\hline Diversification & Diver & $\begin{array}{c}\text { Total Non-interest income / } \\
\text { total income }\end{array}$ & $+/-$ & FCDB \\
\hline \multicolumn{5}{|c|}{ Panel C: Bank Specific variables } \\
\hline Cost to income ratio & $C I R$ & Operating Cost to income ratio & - & $\begin{array}{l}\text { FCDB Authors' } \\
\text { calculation }\end{array}$ \\
\hline $\begin{array}{l}\text { Equity ratio/ } \\
\text { Capitalization }\end{array}$ & EQTA & $\begin{array}{c}\text { The ratio of Equity/Total } \\
\text { Assets }\end{array}$ & + & FCDB \\
\hline Loans ratio & GLTA & Gross loans/Total Assets & - & FCDB \\
\hline Bank size & $T A$ & The logarithm of Total Assets & + & FCDB \\
\hline Islamic & Islamic & $\begin{array}{l}\text { takes the value of } 1 \text { if the bank } \\
\text { is Islamic and } 0 \text { otherwise }\end{array}$ & $+/-$ & \\
\hline \multicolumn{5}{|c|}{ Panel D: Industry-Specific variables } \\
\hline Concentration & $\mathrm{HHI}$ & Market Structure & $+/-$ & FCDB \\
\hline \multicolumn{5}{|c|}{ Panel E: Macroeconomic Variables (Mac) } \\
\hline $\begin{array}{l}\text { Global Financial } \\
\text { Crisis }\end{array}$ & Crisis & $\begin{array}{c}\text { Dummy variable takes a value } \\
\text { of } 1 \text { for the year } 2008-09 \text { and } 0 \\
\text { otherwise }\end{array}$ & - & \\
\hline GDP growth rate & GDPGR & The annual GDP growth rate & + & WDI \\
\hline Inflation rate & INFR & Inflation rate & & WDI \\
\hline
\end{tabular}


Table 2.

\section{Summary Statistics}

This table reports selective descriptive statistics for all the variables used in the study. The Panels A, B, and C summarize the statistics for Full sample, Conventional banks, and for Islamic Banks, respectively. The basic statistics include the number of observations, mean value, standard deviation (Std. Dev.), observations (Obs), maximum (Max) and minimum (Min) values. In this table, zscore represents banks stability. Lerner denotes the inverse measure of competition. Diver denotes the income diversification. TA denotes the bank size, EQTA represent equity to total assets, CIR represents cost to income ratio, and GLTA represents gross loans to total assets. Islamic indicates the dummy variable for Islamic banks, which takes the value of 1 if the bank is Islamic and 0 otherwise. Macroeconomic variables, GDP growth rate (GDPGR), inflation rate (INFR).

\begin{tabular}{|c|c|c|c|c|c|c|c|c|c|c|}
\hline Variable & zscore & Lerner & Diver & $T A$ & EQTA & CIR & GLTA & HHI & GDPGR & INFR \\
\hline \multicolumn{11}{|c|}{ Panel A: Full sample } \\
\hline Obs & 899 & 952 & 968 & 968 & 968 & 968 & 968 & 968 & 968 & 968 \\
\hline Mean & 3.18 & 0.35 & 0.18 & 7.03 & 0.14 & 5.40 & 0.64 & 0.07 & 5.44 & 5.51 \\
\hline Std. Dev. & 1.01 & 0.17 & 0.19 & 1.57 & 0.09 & 30.51 & 0.12 & 0.01 & 0.56 & 1.62 \\
\hline Min & -2.30 & -0.75 & -2.95 & 2.68 & -0.27 & -364.40 & 0.05 & 0.06 & 4.63 & 3.53 \\
\hline Max & 5.78 & 0.95 & 1.23 & 11.28 & 0.86 & 383.86 & 0.99 & 0.09 & 6.35 & 10.23 \\
\hline \multicolumn{11}{|c|}{ Panel B: Conventional Banks } \\
\hline Obs & 844 & 893 & 909 & 909 & 909 & 909 & 909 & 909 & 909 & 909 \\
\hline Mean & 3.19 & 0.35 & 0.18 & 7.04 & 0.15 & 5.26 & 0.64 & 0.07 & 5.44 & 5.52 \\
\hline Std. Dev. & 1.00 & 0.17 & 0.19 & 1.59 & 0.09 & 31.10 & 0.12 & 0.01 & 0.56 & 1.63 \\
\hline Min & -2.30 & -0.75 & -2.95 & 2.68 & -0.27 & -364.40 & 0.05 & 0.06 & 4.63 & 3.53 \\
\hline Max & 5.78 & 0.95 & 1.17 & 11.28 & 0.86 & 383.86 & 0.99 & 0.09 & 6.35 & 10.23 \\
\hline \multicolumn{11}{|c|}{ Panel C: Islamic Banks } \\
\hline Obs & 55 & 59 & 59 & 59 & 59 & 59 & 59 & 59 & 59 & 59 \\
\hline Mean & 2.93 & 0.27 & 0.25 & 6.85 & 0.11 & 7.58 & 0.68 & 0.07 & 5.46 & 5.38 \\
\hline Std. Dev. & 1.12 & 0.13 & 0.19 & 1.34 & 0.06 & 19.13 & 0.11 & 0.01 & 0.56 & 1.45 \\
\hline Min & 1.29 & -0.11 & -0.02 & 3.62 & 0.05 & -64.51 & 0.08 & 0.06 & 4.63 & 3.53 \\
\hline $\operatorname{Max}$ & 5.30 & 0.51 & 1.23 & 8.78 & 0.36 & 112.62 & 0.83 & 0.09 & 6.35 & 10.23 \\
\hline
\end{tabular}

Table 3.

\section{Correlation Analysis}

This table reports the correlation matrix for all the variables using Pearson's correlation test. The statistics in bold are significant. The full names of the variables are in Table 1.

\begin{tabular}{lcccccccccc}
\hline Variable & zscore & Lerner & Diver & TA & EQTA & CIR & GLTA & HHI & GDPGR INFR \\
\hline zscore & 1 & & & & & & & & \\
Lerner & 0.255 & 1 & & & & & & & \\
Diver & -0.101 & 0.235 & 1 & & & & & & \\
TA & 0.0389 & 0.374 & 0.200 & 1 & & & & & \\
EQTA & $\mathbf{0 . 2 5 2}$ & $\mathbf{0 . 1 6 3}$ & -0.0687 & -0.375 & 1 & & & & \\
CIR & -0.0665 & -0.112 & 0.0334 & -0.0286 & -0.0643 & 1 & & & \\
GLTA & -0.0208 & -0.0731 & -0.224 & $\mathbf{0 . 0 6 8 2}$ & -0.123 & 0.0377 & 1 & & \\
HHI & -0.0982 & 0.0120 & $\mathbf{0 . 1 0 7}$ & 0.0226 & -0.107 & 0.0324 & -0.229 & 1 & & \\
GDPGR & -0.0978 & $\mathbf{0 . 0 7 3 2}$ & $\mathbf{0 . 1 1 5}$ & 0.0513 & -0.111 & 0.0295 & -0.0947 & 0.477 & 1 & \\
INFR & -0.0696 & -0.0131 & 0.0508 & -0.0522 & -0.0926 & 0.00752 & 0.00592 & 0.214 & 0.272 & 1 \\
\hline
\end{tabular}




\section{A. Regression Analysis and Results}

This section further addresses the objectives of the study. The section presents the results and discussion on how competition and diversification influence bank stability. In Table 3, we estimate two different model specifications using the system GMM estimator. We estimate M1 and M2 using Equation (1). We estimate M1 including only bank-specific controls, and M2 considering the macroeconomic condition of Indonesia. In Table 4, we obtained the results by estimating Equation (2). Here, we examine the difference in the impact of competition and diversification for Islamic banks. That is, we modified M2 to include additional controls for market structure. Tables 5 and 6 present the regression results from Equations (3) and (4), respectively. The model diagnostics indicate the validity of the model. The number of instruments is less than cross-sections (Roodman, 2009a), the significant AR (2) tests show the consistency of the estimates. The Hansen tests show that the instruments are valid because they are not correlated with the error terms. This means that all the models are free of over-identification and are correctly specified.

Table 4 presents the baseline results on the impact of competition and diversification on stability using Equation (1). The lag dependent variable is highly significant, indicating the persistence in the stability measure, which further justifies the use of a dynamic estimator. The Lerner index shows a positive impact on bank stability, implying that an increase in market power (decrease in competition) results in greater stability. Put differently, a decrease in banks' market power (increase in competition) might lead to lower stability and increase risk. This suggests that an increase in competition makes the banks take on riskier investments making them more fragile. Another possible explanation for this relationship can be that, in high competition, banks compete to capture the market share of deposits by offering higher deposit rates. Banks also cut the lending rates to encourage lending. This can result in higher bank costs and lower bank revenues, thus resulting in a negative effect on bank stability. Moreover, on the lending side, banks also relax the lending conditions, which impede the loan quality of the banks. Hence, banks further face bad debts and nonperforming loans, which decrease bank stability through increased bank risk. This is in line with the competition-fragility view and supports the arguments of Forssbæck and Tanveer (2011), Kabir and Worthington (2017), and Keeley (1990). In Models (1) and (2), the coefficients of diversification show a positive impact on bank stability, suggesting that an increase in income diversification results in greater stability. Diversified banks have more options for activities to choose from and therefore may realize economies of scope and scale. Since diversified banks tend to have greater profitability, they are more stable. This is in line with the studies of Amidu and Wolfe (2013), who also found a positive relationship between diversification and stability.

Banks size appears to be positively impacting bank stability in Model M1 and the impact becomes negative after controlling for macro-level characteristics. This suggests that the impact of bank size might be different when the macro-level characteristics are taken into consideration. Besides that, bigger banks might be better stable because bigger banks tend to perform better and enjoy economies of scale (Beccalli, Anolli, and Borello, 2015). In Model M2, bank size shows a negative impact on bank stability, which might indicate that bigger banks are lesser stable 
due to their size. This may be because it becomes difficult to manage bigger banks as compared to smaller banks (Pawlowska, 2016). Equity ratio appears to be positively impacting zscore, suggesting that higher equity ratio is associated with enhanced stability. This may be because banks with higher equity ratio are more capable of compensating higher risks. A possible explanation for this could be that banks with aggressive lending behavior are able to collect more profits, therefore lending makes them less risky (Mercieca, Schaeck, and Wolfe, 2007). The Islamic dummy appears to be insignificant, suggesting insignificant difference in the level of stability of Islamic banks. GDP growth rate and inflation rate have a negative impact on bank stability, suggesting that banks might be less stable with an increase in GDP growth rate and inflation rate in the country. Interestingly, impact of the global financial crisis (Crisis) on Indonesian banks' stability is positive, indicating that Indonesian banks managed to effectively overcome the effects of the financial crisis. Cost to income ratio does not show any significant impact on bank stability.

Table 4.

Impact of Competition and Diversification on Stability

In this table, we report results for the impact of competition and diversification on banks stability. Mode1 (1) (M1) is estimated with only bank-specific explanatory variables and Model (2) (M2) is modified with country-specific characteristics, where GDP growth rate, inflation rate, and crisis are added to the model. In this table zscore is bank stability. zscore $_{j-1}$ is the one period lag of bank stability. Lerner denotes the inverse measure of competition. Diver denotes the income diversification. TA denotes the bank size, EQTA represent equity to total assets, CIR represents cost to income ratio, and GLTA represents gross loans to total assets. Islamic indicates the dummy variable for Islamic banks, which takes the value of 1 if the bank is Islamic and 0 otherwise. Macroeconomic variables, GDP growth rate (GDPGR), inflation rate (INFR), and Crisis are included in the M2 model. Finally, ${ }^{* * *},{ }^{* *}$, and * denote statistical significance at the $1 \%, 5 \%$, and $10 \%$ levels, respectively. $p$-values are in parentheses.

\begin{tabular}{|c|c|c|}
\hline Description & zscore & zscore \\
\hline & M1 & M2 \\
\hline zscore $_{j t-1}$ & $\begin{array}{l}0.3200^{*+4+} \\
(0.000)\end{array}$ & $\begin{array}{l}0.3252^{*+*+1} \\
(0.000)\end{array}$ \\
\hline Lerner & $\begin{array}{l}0.5481^{\text {tw+ }} \\
(0.000)\end{array}$ & $\begin{array}{l}0.5672^{* * *} \\
(0.000)\end{array}$ \\
\hline Diver & $\begin{array}{l}0.3221^{* *+4} \\
(0.000)\end{array}$ & $\begin{array}{l}0.3440^{*+*+} \\
(0.000)\end{array}$ \\
\hline $\mathrm{T} A$ & $\begin{array}{l}0.0185^{*+*} \\
(0.006)\end{array}$ & $\begin{array}{l}-0.0338^{* * * *} \\
(0.006)\end{array}$ \\
\hline EQTA & $\begin{array}{l}4.3288^{n+1+} \\
(0.000)\end{array}$ & $\begin{array}{l}4.1898^{*+*} \\
(0.000)\end{array}$ \\
\hline CIR & $\begin{array}{l}-0.0001 \\
(0.262)\end{array}$ & $\begin{array}{l}-0.0001 \\
(0.143)\end{array}$ \\
\hline GLTA & $\begin{array}{l}0.0442 \\
(0.253)\end{array}$ & $\begin{array}{l}0.2559^{*+*} \\
(0.000)\end{array}$ \\
\hline Islamic & $\begin{array}{l}-0.1109 \\
(0.319)\end{array}$ & $\begin{array}{l}-0.1143 \\
(0.308)\end{array}$ \\
\hline GDPGR & & $\begin{array}{l}-0.0311^{* *+*} \\
(0.000)\end{array}$ \\
\hline INFR & & $\begin{array}{l}-0.0107^{* * *} \\
(0.000)\end{array}$ \\
\hline Crisis & & $\begin{array}{l}0.0264^{* * *} \\
(0.008)\end{array}$ \\
\hline Constant & $\begin{array}{l}1.1946^{4+*} \\
(0.000)\end{array}$ & $\begin{array}{l}1.6520^{*+*+*} \\
(0.000)\end{array}$ \\
\hline
\end{tabular}


Table 4.

Impact of Competition and Diversification on Stability (Continued)

\begin{tabular}{llll}
\hline \multicolumn{1}{c}{ Description } & \multicolumn{2}{c}{ zscore } & zscore \\
\hline & \multicolumn{1}{c}{ M1 } & M2 \\
\hline Observations & 764 & 764 & \\
Instruments & 78.0000 & 80.0000 & \\
Groups & 116.0000 & 116.0000 \\
$A R(1)$ & $(0.0422)$ & $(0.0333)$ \\
$A R(2)$ & $(0.1633)$ & $(0.1826)$ \\
Hansen-PV & $(0.2525)$ & $(0.2411)$ \\
\hline
\end{tabular}

B. Impact of Competition and Diversification on Stability (Islamic vs Conventional Banks) Table 5 presents the baseline results obtained by estimating Equation (2), models the difference in the impact of competition and diversification on stability for Islamic vs conventional banks. The results suggest that there is a difference in the impact of competition and diversification for conventional banks and Islamic banks. The Islamic dummy appears to be negative and significant, indicating that Islamic banks are less stable than their conventional counterparts. One of the possible arguments for this finding might be that conventional banks are bigger than Islamic banks, which makes them more stable (Alaeddin, Khattak, and Abojeib, 2019). These findings are in line with Wahid and Dar (2016), who compare the stability of Islamic and conventional banks in Malaysia and found that Islamic banks are lesser stable. The coefficient of the Lerner index is insignificant for conventional banks and is significant for Islamic banks, thus supporting the competition-fragility view. A good explanation is This might be due to a large number of conventional banks, which, one might say, is the mature sector of the country and the fact that Islamic banks are facing immense competition from both conventional and Islamic banks (Beck, Demirgüç-Kunt, and Merrouche, 2013). Moreover, diversification only impacts conventional banks. Figures 1 and 2 show the marginal impact of the Lerner index and diversification on stability, which confirm the significant difference in the impact of competition and diversification for Islamic and conventional banks. Among the controls, only equity ratio shows a positive impact and is in line with the earlier findings in Table 4. 
Table 5.

Impact of Competition and Diversification on Stability (Islamic vs Conventional)

In this table, we report the results for the impact of competition and diversification on banks stability for Islamic and conventional banks. Mode1 (2) is modified with an additional control variable for market concentration (HHI). Finally, $* * *, * *$, and ${ }^{*}$ denote statistical significance at the $1 \%, 5 \%$, and $10 \%$ levels, respectively. $p$-values are in parentheses.

\begin{tabular}{|c|c|c|}
\hline Description & zscore & zscore \\
\hline & M1 & M2 \\
\hline zscore $_{t-1}$ & $\begin{array}{c}0.4046^{* * *} \\
(0.000)\end{array}$ & $\begin{array}{l}0.4002^{\text {stot }} \\
(0.000)\end{array}$ \\
\hline Lerner & $\begin{array}{l}0.3518 \\
(0.298)\end{array}$ & $\begin{array}{l}0.3576 \\
(0.291)\end{array}$ \\
\hline Diver & $\begin{array}{l}0.3013^{* * * *} \\
(0.000)\end{array}$ & $\begin{array}{l}0.3018^{*+*+1} \\
(0.000)\end{array}$ \\
\hline$T A$ & $\begin{array}{l}-0.0247 \\
(0.609)\end{array}$ & $\begin{array}{l}-0.0243 \\
(0.617)\end{array}$ \\
\hline EQTA & $\begin{array}{l}3.4803^{* * x} \\
(0.000)\end{array}$ & $\begin{array}{l}3.4587^{+4+4} \\
(0.000)\end{array}$ \\
\hline$C I R$ & $\begin{array}{l}0.0003 \\
(0.471)\end{array}$ & $\begin{array}{l}0.0002 \\
(0.526)\end{array}$ \\
\hline GLTA & $\begin{array}{c}-0.1441 \\
(0.596)\end{array}$ & $\begin{array}{l}-0.1350 \\
(0.632)\end{array}$ \\
\hline Islamic & $\begin{array}{c}-0.6974^{* * *} \\
(0.015)\end{array}$ & $\begin{array}{l}-0.7008^{* *} \\
(0.014)\end{array}$ \\
\hline GDPGR & $\begin{array}{l}-0.0421 \\
(0.144)\end{array}$ & $\begin{array}{l}-0.0476 \\
(0.124)\end{array}$ \\
\hline INFR & $\begin{array}{l}-0.0000 \\
(0.995)\end{array}$ & $\begin{array}{l}0.0008 \\
(0.883)\end{array}$ \\
\hline Crisis & $\begin{array}{l}-0.0566 \\
(0.284)\end{array}$ & $\begin{array}{l}-0.0719 \\
(0.209)\end{array}$ \\
\hline Lerner * Islamic & $\begin{array}{c}2.5406^{* * *} \\
(0.003)\end{array}$ & $\begin{array}{l}2.5423^{*+*+1} \\
(0.003)\end{array}$ \\
\hline Islamic * Diver & $\begin{array}{l}0.1792 \\
(0.548)\end{array}$ & $\begin{array}{l}0.1908 \\
(0.523)\end{array}$ \\
\hline HHI & & $\begin{array}{l}0.6755 \\
(0.704)\end{array}$ \\
\hline Constant & $\begin{array}{c}1.7597^{* * *} \\
(0.007) \\
\end{array}$ & $\begin{array}{c}1.7457^{\prime+*+*} \\
(0.010)\end{array}$ \\
\hline Observations & 764 & 764 \\
\hline Instruments & 23.0000 & 24.0000 \\
\hline Groups & 116.0000 & 116.0000 \\
\hline$A R(1)$ & $(0.0187)$ & $(0.0196)$ \\
\hline$A R(2)$ & $(0.7019)$ & $(0.7360)$ \\
\hline Hansen-PV & $(0.1402)$ & $(0.1449)$ \\
\hline
\end{tabular}


Figure 1.

Marginal Effects of Diversification on Stability (Conventional vs Islamic)

The figure shows the marginal impact of diversification on stability for conventional banks and Islamic banks. It appears that diversification does not show a significant evidence of impact for Islamic banks. For conventional banks, however, the impact is positively significant.

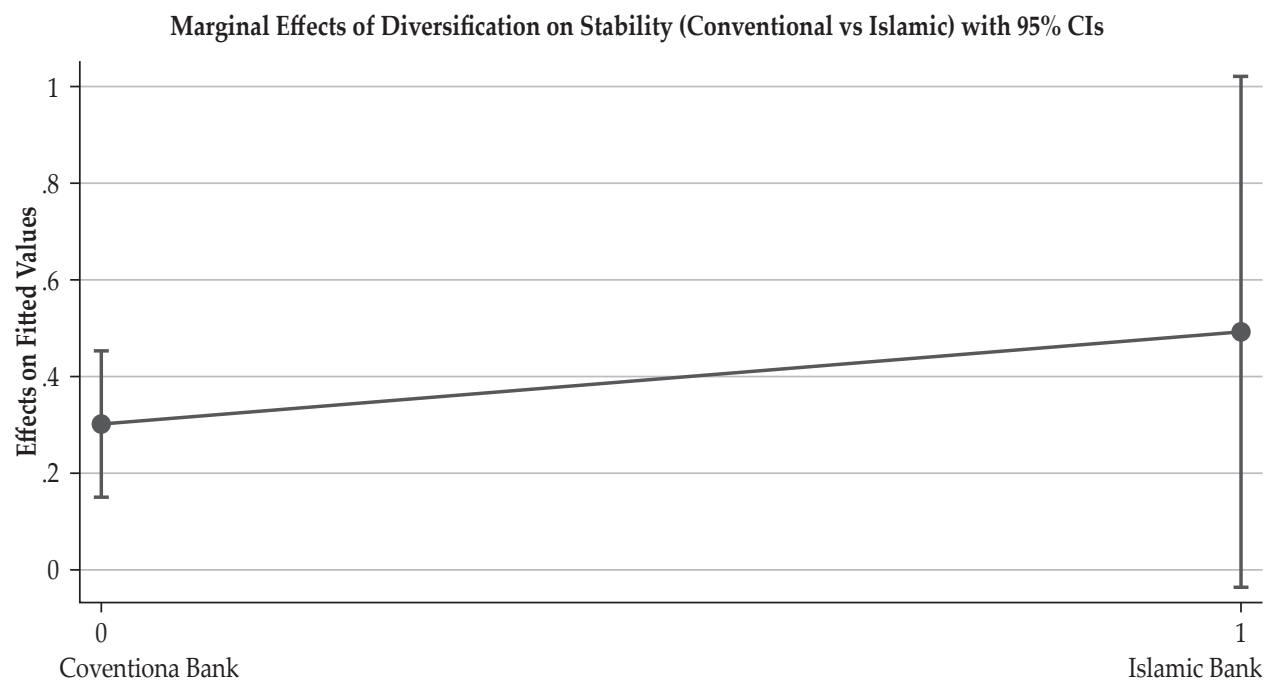

Figure 2.

Marginal effects of Lerner index on Stability (Conventional vs Islamic)

The figure shows the marginal impact of Lerner index on stability for conventional banks and Islamic banks. It appears that the Lerner index does not show a significant evidence of impact for conventional banks. For Islamic banks, however, the impact is positively significant.

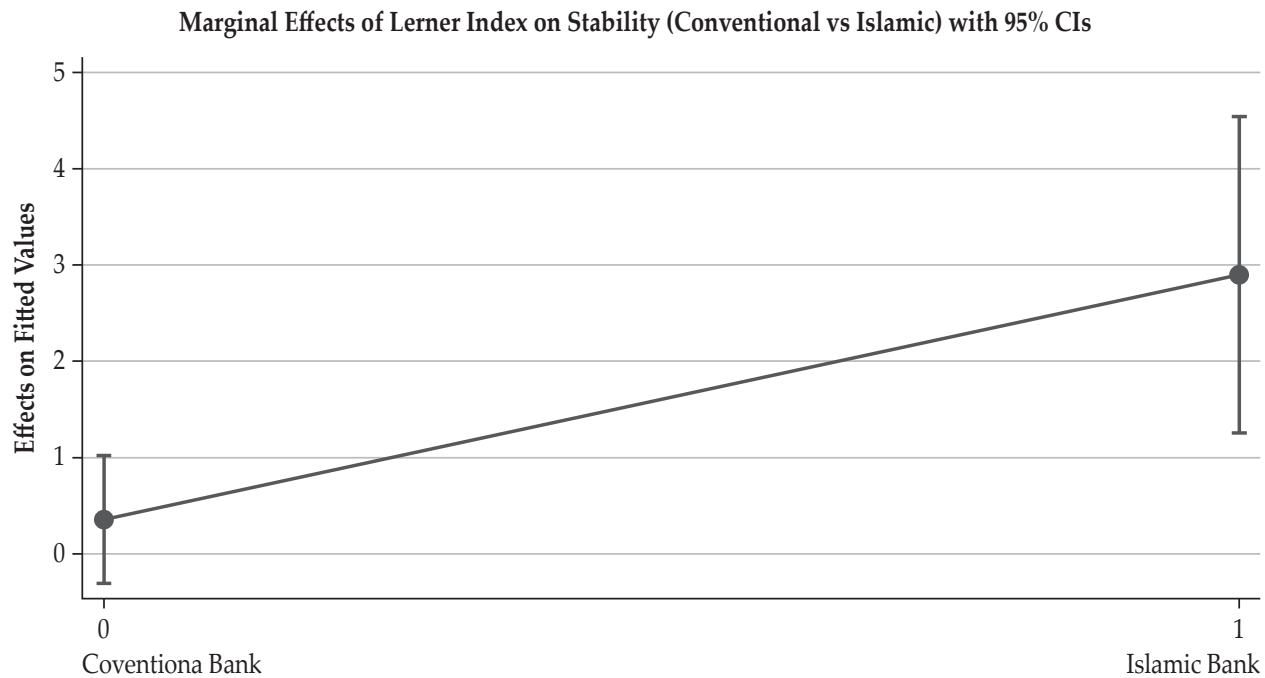




\section{Impact of the Interaction between Competition and Diversification on Stability}

Table 6 shows that results on the moderating role of competition and diversification in shaping the relationship of either variable with stability using Equation (3). The interaction term (Lerner*Diversification) shows a negative and significant moderating role. Figures 3 and 4 show the marginal impact of the interaction of the Lerner index and diversification. We plot the marginal impact of the Lerner index on stability as diversification changes in Figure 3, which shows that the impact of the Lerner index decreases as the level of diversification increases. Put differently, the impact of competition increases with a rise in diversification. This suggests that diversification can be used as a tool to avoid the negative impact of competition on bank stability, as found in earlier results in Table 3. Figure 4 shows the role of the Lerner index in shaping the relationship between diversification and stability. The figure suggests that the impact of diversification decreases as the Lerner index increases. In other words, the impact of diversification decreases with a decrease in competition and the impact is only significant below and above the moderate level of competition. Figures 3 and 4 together suggest that competition in the market and the level of diversification complement each other to enhance the level of stability. Therefore, one can be used to make up for the impact of the other on stability.

Table 6.

\section{Impact of the Interaction between Competition and Diversification on Stability}

In this table, we report the results for the impact of the interaction between competition and diversification on banks stability. Mode1 (2) is modified with an additional control variable for market concentration $(H H I)$. Finally, ${ }^{* * *},{ }^{* *}$, and

* denote statistical significance at the $1 \%, 5 \%$, and $10 \%$ levels, respectively. $p$-values are in parentheses.

\begin{tabular}{|c|c|c|}
\hline Description & zscore & zscore \\
\hline & M1 & M2 \\
\hline zscore $_{t-1}$ & $\begin{array}{c}0.3338^{* * *+} \\
(0.000)\end{array}$ & $\begin{array}{c}0.3343^{*+*+4} \\
(0.000)\end{array}$ \\
\hline Lerner & $\begin{array}{c}0.7860^{* * *+*} \\
(0.000)\end{array}$ & $\begin{array}{c}0.8211^{*+4+4} \\
(0.000)\end{array}$ \\
\hline Diver & $\begin{array}{c}0.3152^{*+*} \\
(0.000)\end{array}$ & $\begin{array}{c}0.3269^{*+*+*} \\
(0.000)\end{array}$ \\
\hline Lerner ${ }^{*}$ Diver & $\begin{array}{c}-0.6847^{\text {sat }} \\
(0.000)\end{array}$ & $\begin{array}{c}-0.6730^{+3 x+7} \\
(0.000)\end{array}$ \\
\hline TA & $\begin{array}{c}-0.0409= \\
(0.000)\end{array}$ & $\begin{array}{c}-0.0661^{* x+4} \\
(0.000)\end{array}$ \\
\hline EQTA & $\begin{array}{c}3.9941^{*+*+} \\
(0.000)\end{array}$ & $\begin{array}{c}4.0327^{*} \\
(0.000)\end{array}$ \\
\hline$C I R$ & $\begin{array}{c}-0.0001^{* *+4} \\
(0.000)\end{array}$ & $\begin{array}{r}-0.0000^{*} \\
(0.072)\end{array}$ \\
\hline GLTA & $\begin{array}{c}0.1713^{*+*+*} \\
(0.000)\end{array}$ & $\begin{array}{l}0.1673^{2+*+1} \\
(0.000)\end{array}$ \\
\hline GDPGR & $\begin{array}{c}-0.0275^{*+*+} \\
(0.000)\end{array}$ & $\begin{array}{c}-0.0339^{*+0 \times+} \\
(0.000)\end{array}$ \\
\hline INFR & $\begin{array}{c}-0.0100 *+1 \\
(0.000)\end{array}$ & $\begin{array}{c}-0.0065^{6+0} \\
(0.000)\end{array}$ \\
\hline Islamic & $\begin{array}{c}-0.2023^{* *} \\
(0.029)\end{array}$ & $\begin{array}{c}-0.1608^{* *} \\
(0.038)\end{array}$ \\
\hline
\end{tabular}


Table 6.

Impact of the Interaction between Competition and Diversification on Stability (Continued)

\begin{tabular}{lcc}
\hline Description & zscore & zscore \\
\hline \multirow{2}{*}{ Crisis } & M1 & M2 \\
& $0.0210^{* * *+}$ & $-0.0347^{* * *}$ \\
HHI & $(0.001)$ & $(0.000)$ \\
& & 0.3471 \\
Constant & & $(0.336)$ \\
& $1.6964^{* * *+*}$ & $1.8598^{* * *}$ \\
Observations & $(0.000)$ & $(0.000)$ \\
Instruments & 764 & 764 \\
Groups & 91.0000 & 92.0000 \\
AR(1) & 116.0000 & 116.0000 \\
AR(2) & $(0.0284)$ & $(0.0332)$ \\
Hansen-PV & $(0.0951)$ & $(0.0984)$ \\
\hline
\end{tabular}

Figure 3.

\section{Marginal Effects of Diversification on Stability as Lerner index Varies}

The figure shows the marginal impact of diversification on the stability of the entire banking sector of Indonesia as the Lerner index increases. It appears that the impact of diversification is negatively significant at low and high levels of market power.

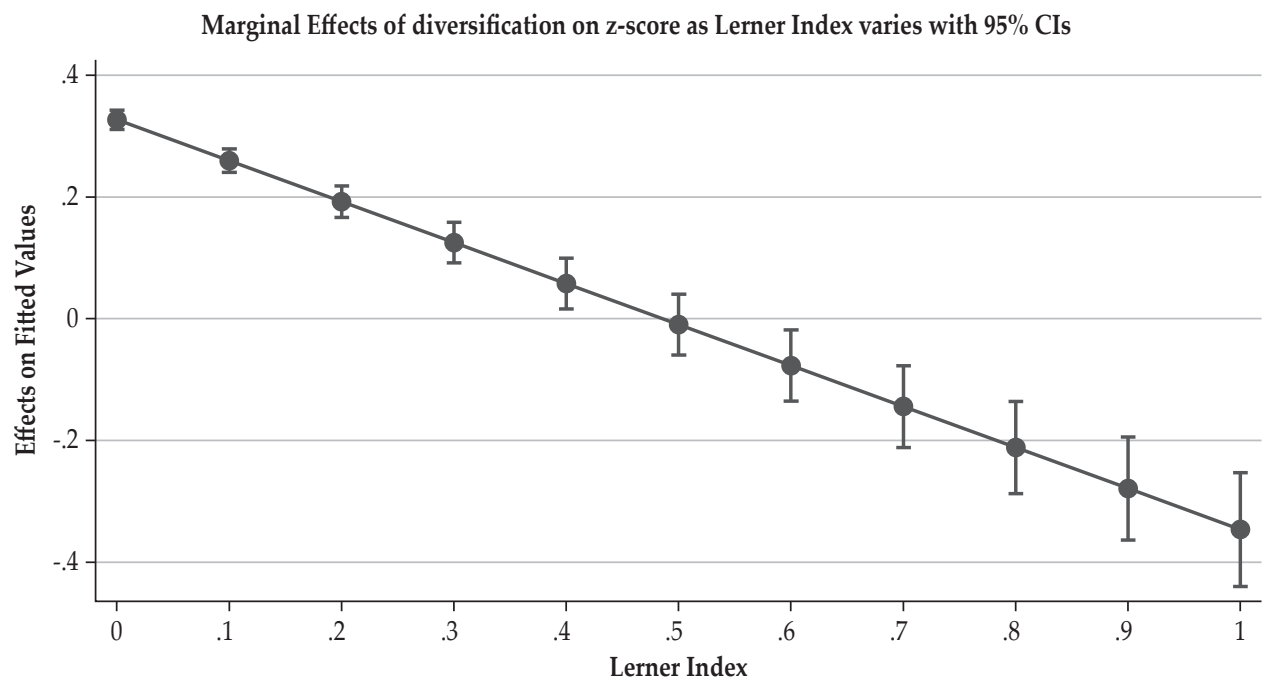


Figure 4.

Marginal Effects of Lerner index on Stability as Diversification Varies

The figure shows the marginal impact of the Lerner index on the stability of the entire banking sector of Indonesia. It appears that the impact of Lerner index is negatively significant as diversification increases.

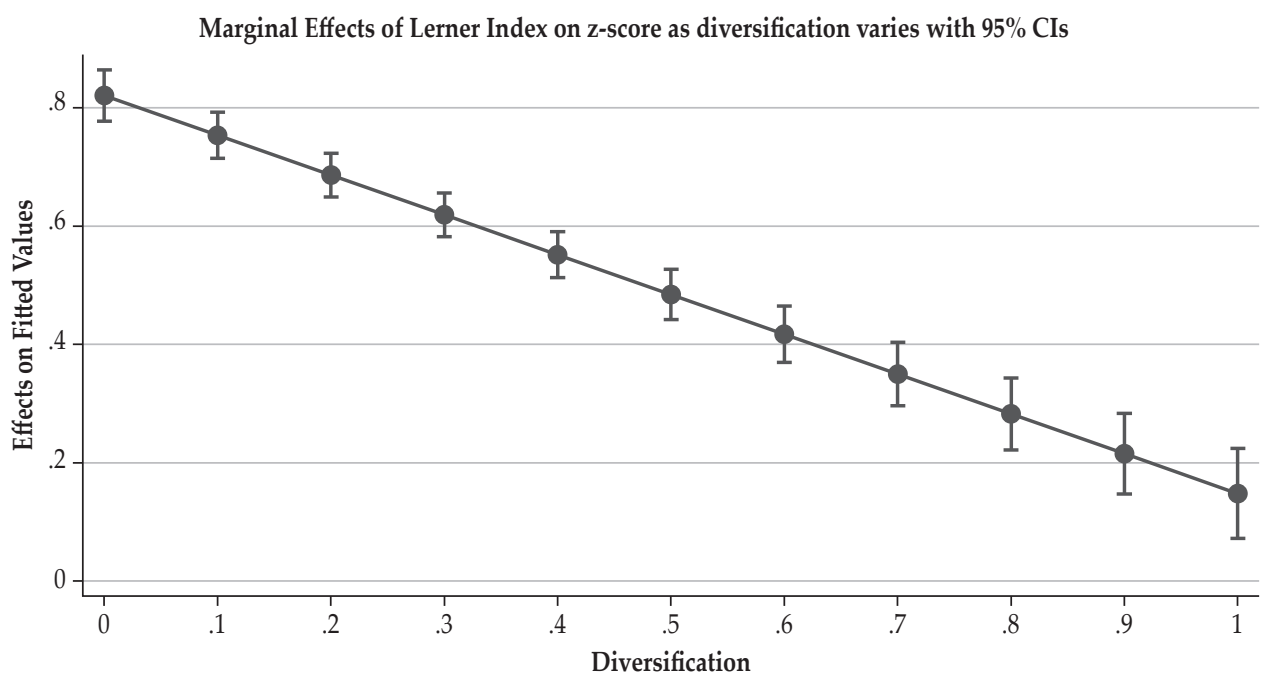

D. Impact of the Interaction between Competition and Diversification on Stability (Conventional vs Islamic Banks)

Using Equation (4), Table 7 extends the results in Table 6 and examines whether the moderating role of diversification and competition is different for Islamic banks. For brevity and simplicity, we only focus on the interaction term, Lerner* Diversification, and the 3-way interaction term, Lerner*Diversification*Islamic. The coefficients of interaction terms show an insignificant impact on conventional banks (Lerner* Diversification) and show a positive significant impact on Islamic banks (Lerner*Diversification*Islamic). Figures 5 and 6 show the marginal impact of the Lerner index and diversification on stability for Islamic and conventional banks. Figure 5 suggests that diversification does not play a significant role in the relationship between competition and stability in the case of conventional banks. However, the figure shows a very different picture for Islamic banks, suggesting that, as diversification increases, the impact of the Lerner index increases as well. In other words, the impact of competition decreases with an increase in the level of diversification for Islamic banks. Islamic banks are argued to diversify their portfolios to avoid the negative implications of competition for stability (Azmi et al. 2019). Furthermore, Figure 6 presents the marginal impact of diversification on stability, as the Lerner index changes for Islamic and conventional banks. The figure does not provide any significant evidence of the role of the Lerner index in the case of conventional banks. For Islamic banks, the figure suggests that the impact of diversification increases with a decrease in competition, and the moderating role is only significant at a high level of competition. 
Table 7.

Impact of the Interaction between Competition and Diversification on Stability (Conventional vs Islamic)

In this table, we report the results for the impact of the interaction between competition and diversification on banks stability for Islamic banks and conventional banks. Mode1 (2) is modified with an additional control variable for market concentration (HHI). Finally, ${ }^{* * *}, * *$, and * denote statistical significance at the $1 \%, 5 \%$, and $10 \%$ levels, respectively. $p$-values are in parentheses.

\begin{tabular}{|c|c|c|}
\hline Description & zscore & zscore \\
\hline & M1 & M2 \\
\hline zscore $_{t-1}$ & $\begin{array}{c}0.9195^{* * *} \\
(0.000)\end{array}$ & $\begin{array}{c}0.9286^{\text {wat }} \\
(0.000)\end{array}$ \\
\hline Lerner & $\begin{array}{l}-0.0043 \\
(0.956)\end{array}$ & $\begin{array}{l}-0.0405 \\
(0.624)\end{array}$ \\
\hline Diver & $\begin{array}{l}0.0446 \\
(0.275)\end{array}$ & $\begin{array}{l}0.0273 \\
(0.563)\end{array}$ \\
\hline Lerner * Diver & $\begin{array}{l}-0.1568 \\
(0.288)\end{array}$ & $\begin{array}{l}-0.1249 \\
(0.410)\end{array}$ \\
\hline Islamic & $\begin{array}{l}0.0081 \\
(0.890)\end{array}$ & $\begin{array}{l}0.0163 \\
(0.783)\end{array}$ \\
\hline Lerner * Islamic & $\begin{array}{l}0.0230 \\
(0.932)\end{array}$ & $\begin{array}{l}0.0163 \\
(0.950)\end{array}$ \\
\hline Diver * Islamic & $\begin{array}{c}-0.4429^{* * *+*} \\
(0.000)\end{array}$ & $\begin{array}{c}-0.4266^{*+4} \\
(0.000)\end{array}$ \\
\hline Lerner * Diver * Islamic & $\begin{array}{l}1.3061^{* * *+} \\
(0.008)\end{array}$ & $\begin{array}{l}1.2232^{* *} \\
(0.011)\end{array}$ \\
\hline$T A$ & $\begin{array}{c}0.0180^{* * *+} \\
(0.001)\end{array}$ & $\begin{array}{c}0.0198^{* *+*} \\
(0.000)\end{array}$ \\
\hline EQTA & $\begin{array}{l}1.0508^{* * * x} \\
(0.000)\end{array}$ & $\begin{array}{c}1.0537^{3+*} \\
(0.000)\end{array}$ \\
\hline$C I R$ & $\begin{array}{l}0.0002 \\
(0.400)\end{array}$ & $\begin{array}{l}0.0002 \\
(0.279)\end{array}$ \\
\hline GLTA & $\begin{array}{l}-0.0695 \\
(0.370)\end{array}$ & $\begin{array}{l}-0.0397 \\
(0.650)\end{array}$ \\
\hline GDPGR & $\begin{array}{l}-0.0024 \\
(0.747)\end{array}$ & $\begin{array}{l}-0.0067 \\
(0.444)\end{array}$ \\
\hline INFR & $\begin{array}{c}-0.0107^{*+1+} \\
(0.000)\end{array}$ & $\begin{array}{c}-0.0106^{* *+*} \\
(0.000)\end{array}$ \\
\hline $\mathrm{HHI}$ & & $\begin{array}{l}0.9327 \\
(0.162)\end{array}$ \\
\hline Constant & $\begin{array}{l}0.1154 \\
(0.259) \\
\end{array}$ & $\begin{array}{l}0.0244 \\
(0.860)\end{array}$ \\
\hline Observations & 764 & 764 \\
\hline Instruments & 59.0000 & 60.0000 \\
\hline Groups & 116.0000 & 116.0000 \\
\hline$A R(1)$ & $(0.0090)$ & $(0.0088)$ \\
\hline$A R(2)$ & $(0.0217)$ & $(0.0207)$ \\
\hline Hansen-PV & $(0.0878)$ & $(0.0887)$ \\
\hline
\end{tabular}


Figure 5.

Marginal impact of the Lerner index on stability as diversification varies (Islamic vs Conventional)

The figure shows the marginal impact of the Lerner index on the stability of conventional and Islamic banks as the diversification increases. It appears that the impact of the Lerner index is only significant for Islamic banks.

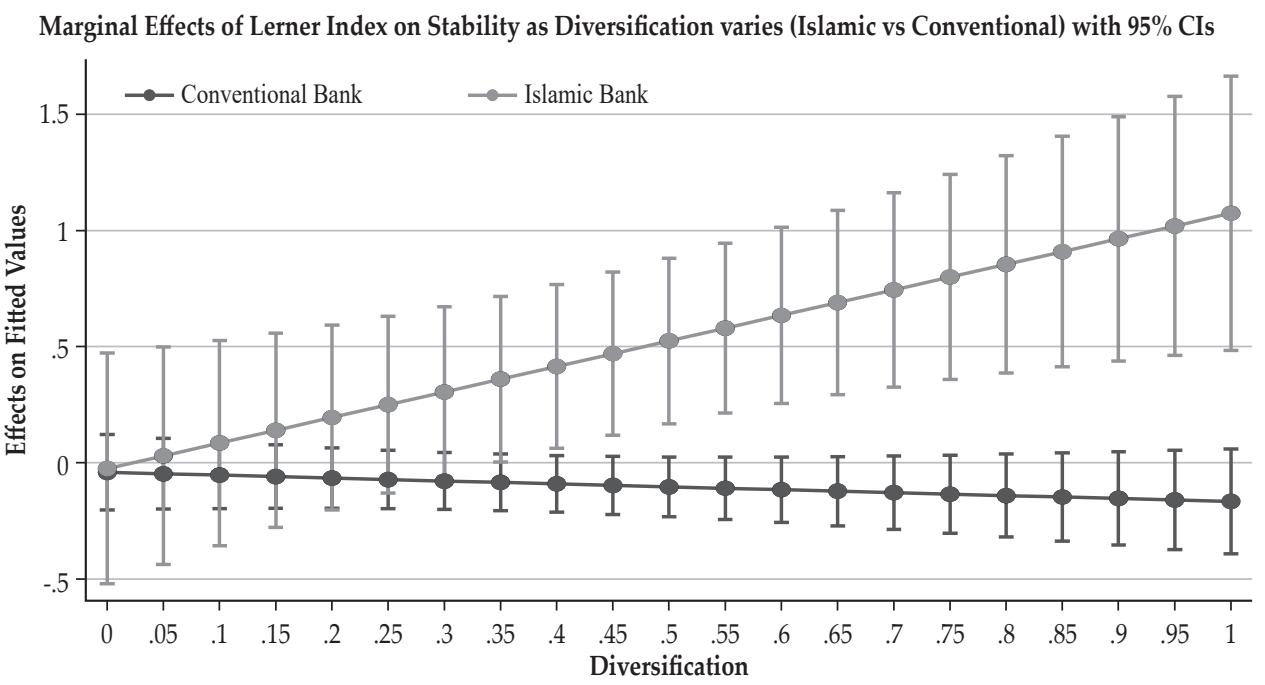

Figure 6.

Marginal impact of Diversification on stability as Lerner index Varies (Islamic vs Conventional)

The figure shows the marginal impact of diversification on the stability of conventional and Islamic banks as the Lerner index increases. The figure shows that the impact of diversification is only significant for Islamic banks at low level of market power.

Marginal Effects of Diversification on Stability as Lerner Index varies (Islamic vs Conventional) with 95\% CIs

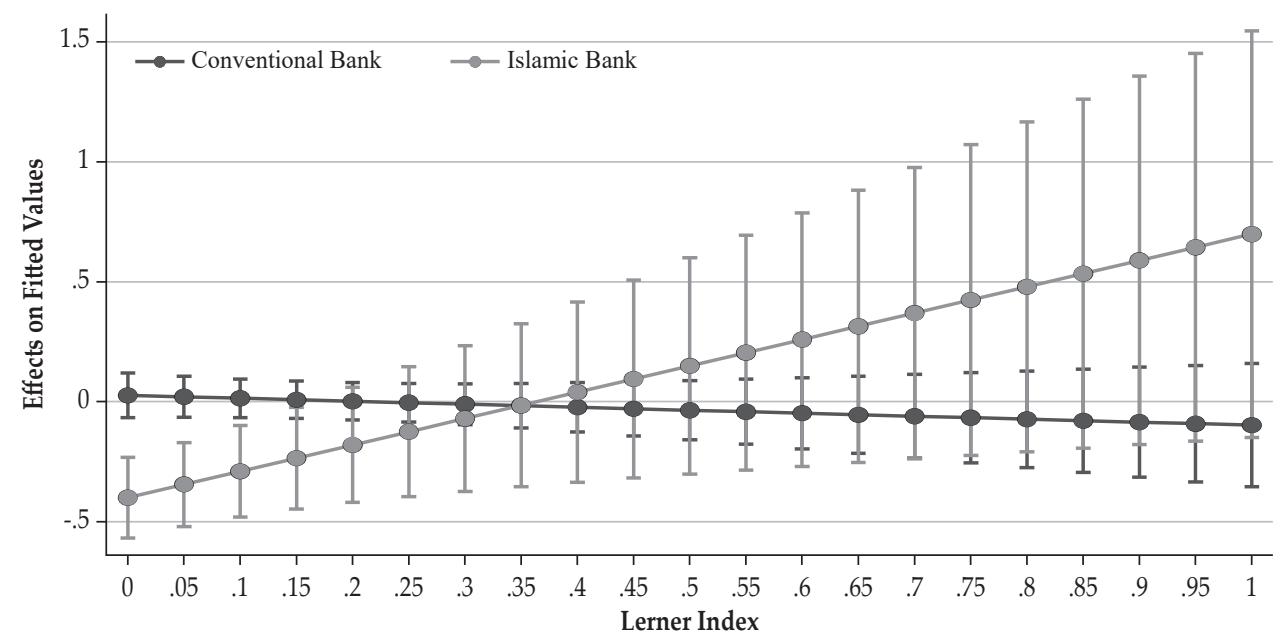




\section{E. Robustness Checks}

The skewness in our dataset (with 110 conventional and only 13 Islamic banks) limits our ability to split the sample into Islamic and conventional banks and reestimate the baseline models. Therefore, we use dummy interactions instead. For robustness tests, using different panel estimators might be an option. However, the dummy variable for Islamic banks will be omitted using the difference GMM and fixed effect estimators due to the $0 / 1$ within differences. ${ }^{8}$ Thus, we extend our model by including additional variables and try different model specifications to seek robustness for our findings. These results are reported in Table 8. Following the recent work of Ali and Khattak (2020) on Indonesia, we use the ratio of loan/ financing loss provisions to total assets $(L L P)$ and the ratio of deposits to total assets (CDTA) as additional bank-specific variables. Besides that, we replace the GDP growth rate and inflation rate with GDP per capita growth rate. In Table 8, we re-estimate the models and found that the results are robust to different model specifications. In Model (1), the Lerner index does not show a significant impact in the case of conventional banks and shows a highly positive and significant impact for Islamic banks, supporting the competition-fragility view and is in line with the earlier findings of Table 4 . Diversification shows a significant impact on the conventional banks and an insignificant impact on Islamic banks. It seems that conventional banks benefit from portfolio diversification and enjoy greater stability, unlike Islamic banks.

Table 8.

\section{Robustness: Impact of Interaction between Competition and Diversification on Stability (Conventional vs Islamic)}

In this table, we the report results for the impact of non-intermediation income on banks performance. Models (1), (2) and (3) are re-estimated by including additional variables to add credence to the results in Tables (5), (6), and (7), respectively. The additional variables are deposits ratio (CDTA), loan loss provisions (LLP) and GDP per capita growth rate $(G D P C)$ are added and GDPGR and Inflation are excluded from the model. Finally, ${ }^{* * *}, * *$, and ${ }^{*}$ denote statistical significance at the $1 \%, 5 \%$, and $10 \%$ levels, respectively. Standard errors are in parentheses.

\begin{tabular}{lccc}
\hline \multirow{2}{*}{ Description } & zscore & zscore & zscore \\
\cline { 2 - 4 } & M1 & M2 & M3 \\
\hline \multirow{2}{*}{ score $_{\text {t- }}$} & $0.4967^{* * * *}$ & $0.3128^{* * * *}$ & $0.9097^{* * *}$ \\
Lerner & $(0.000)$ & $(0.000)$ & $(0.000)$ \\
& -0.2547 & $0.5884^{* * * *}$ & -0.0118 \\
Diver & $(0.216)$ & $(0.000)$ & $(0.886)$ \\
& $0.3660^{* * *}$ & $0.3945^{* * *}$ & 0.0090 \\
Lerner ${ }^{*}$ Islamic & $(0.000)$ & $(0.000)$ & $(0.821)$ \\
\multirow{2}{*}{ Islamic * Diver } & $2.4078^{* * * *}$ & & -0.1343 \\
& $(0.002)$ & & $(0.635)$ \\
TA & 0.3180 & & $-0.2861^{* *}$ \\
& $(0.168)$ & & $(0.012)$ \\
EQTA & $0.0491^{*}$ & -0.0039 & $0.0254^{* * * *}$ \\
& $(0.095)$ & $(0.630)$ & $(0.000)$ \\
\end{tabular}

8 Initially, we tried to use non-performing loans; however, we found missing data for over 300 observations in the dataset obtained from Fitch Connect. Therefore, to avoid any ambiguous and unreliable results, we do not rely on non-performing loans. 
Table 8.

Robustness: Impact of Interaction between Competition and Diversification on Stability (Conventional vs Islamic) (Continued)

\begin{tabular}{|c|c|c|c|}
\hline \multirow{2}{*}{ Description } & zscore & zscore & zscore \\
\hline & M1 & M2 & M3 \\
\hline CIR & $\begin{array}{l}-0.0002 \\
(0.564)\end{array}$ & $\begin{array}{c}-0.0001^{* *} \\
(0.049)\end{array}$ & $\begin{array}{l}0.0003 \\
(0.118)\end{array}$ \\
\hline GLTA & $\begin{array}{c}-0.1251 \\
(0.381)\end{array}$ & $\begin{array}{c}-0.4603^{n+4+} \\
(0.000)\end{array}$ & $\begin{array}{l}-0.0359 \\
(0.629)\end{array}$ \\
\hline HHI & $\begin{array}{l}1.9286 \\
(0.180)\end{array}$ & $\begin{array}{c}-2.2415^{* * *+} \\
(0.000)\end{array}$ & $\begin{array}{l}0.5576 \\
(0.310)\end{array}$ \\
\hline CDTA & $\begin{array}{c}0.5255^{* * *} \\
(0.008)\end{array}$ & $\begin{array}{c}0.7756^{* * *} \\
(0.000)\end{array}$ & $\begin{array}{l}0.1383^{* * *} \\
(0.011)\end{array}$ \\
\hline LLP & $\begin{array}{c}-0.0388^{* * *+} \\
(0.000)\end{array}$ & $\begin{array}{c}-0.0291^{*+4+4} \\
(0.000)\end{array}$ & $\begin{array}{l}0.0008 \\
(0.842)\end{array}$ \\
\hline GDPC & $\begin{array}{c}-0.0489^{* * *+} \\
(0.004)\end{array}$ & $\begin{array}{c}-0.0301^{*+4} \\
(0.000)\end{array}$ & $\begin{array}{l}-0.0043 \\
(0.640)\end{array}$ \\
\hline Islamic & $\begin{array}{c}-0.8751^{* * *+} \\
(0.000)\end{array}$ & $\begin{array}{l}-0.1242 \\
(0.231)\end{array}$ & $\begin{array}{l}0.0352 \\
(0.527)\end{array}$ \\
\hline Crisis & $\begin{array}{l}-0.0600 \\
(0.103)\end{array}$ & $\begin{array}{c}-0.0382^{*+*+*} \\
(0.002)\end{array}$ & \\
\hline Lerner * Diver & & $\begin{array}{c}-1.4193^{*+*+} \\
(0.000)\end{array}$ & $\begin{array}{r}-0.2590 \\
(0.097)\end{array}$ \\
\hline Lerner * Diver ${ }^{*}$ Islamic & & & $\begin{array}{l}1.1706^{* *} \\
(0.039)\end{array}$ \\
\hline Constant & $\begin{array}{l}0.7537^{* *} \\
(0.029) \\
\end{array}$ & $\begin{array}{c}1.5657^{*+* *} \\
(0.000) \\
\end{array}$ & $\begin{array}{r}-0.1569 \\
(0.202) \\
\end{array}$ \\
\hline$A R(1)$ & $(0.0243)$ & $(0.0257)$ & $(0.0107)$ \\
\hline$A R(2)$ & $(0.9512)$ & $(0.9543)$ & $(0.0386)$ \\
\hline Hansen-PV & $(0.0499)$ & (0.1989) & $(0.1892)$ \\
\hline
\end{tabular}

Moving to Model (2), the coefficient of the interaction term (Lerner *Diversification) is negatively significant and is consistent with the earlier findings. In Model (3), the interaction term for conventional banks (Lerner ${ }^{*}$ Diversification) does not show any significant impact, suggesting that there is no moderating impact of competition or diversification on the stability of conventional banks. For Islamic banks, the 3-way interaction term is positively significant, indicating a significant role of diversification and competition. These findings are in line with the earlier findings in Table 6. The impact of CTDA is found to be positive for all the models, suggesting that an increase in customer deposits results in enhanced stability. The loan loss provision ratio shows a negative impact on stability, suggesting that an increase in the LLP reduces the level of bank stability. These results are in line with the findings of Ali and Khattak (2020).

\section{CONCLUSION AND POLICY RECOMMENDATIONS}

This research achieves five objectives. Firstly, it examines the impact of competition on bank stability. Secondly, it examines the impact of diversification on bank 
stability, Thirdly, it examines whether the impact of competition and diversification on stability is different for Islamic banks. Fourthly, it examines the moderating role of competition and diversification in the relationship of either variable with bank stability for the overall sample. Lastly, it explores whether there is any difference in the moderating role of competition and diversification in the relationship between either variable and stability for Islamic banks and conventional banks. We do this by studying 123 banks in Indonesia from the period 2007-2018.

For the full sample, we found that Islamic banks are less stable as compared to conventional banks. The findings suggest that competition among Indonesian banks appears to be reducing the stability and portfolio diversification, which seems to be enhancing stability. Upon analysis of the difference in the impact for Islamic banks, we found that competition negatively impacts the Islamic banks, but diversification has no impact. We further found a negative moderating role for competition and diversification, suggesting that these variables can complement each other in enhancing the level of stability in the overall Indonesian banking sector. Further analysis suggests a difference in the moderating role for Islamic banks, whereby the moderating role only appears to be significant for Islamic banks.

These results carry important policy implications for the banking sector of Indonesia. Firstly, to ensure stability, policymakers and regulators should encourage portfolio diversification and control competition in the banking sector. Since the Islamic banks are less stable and are more vulnerable to competition, competition within Islamic banks should be given extra attention. Given that diversification and competition can complement each in achieving enhanced stability, banks' management, policymakers, and regulators can use diversification and competition in the banking sector to ensure the stability of the country's banking sector.

This research also carries some limitations, we rely on the Fitch Connect database for classification of banks. Besides that, missing information on risk proxies does not allow us to conduct robustness tests using different risk proxies like non-performing loans. The availability of more accurate data would have led to more robust findings. To get more objective policy implications, we recommend studying the impact of different factors of income diversification and banking competition on bank stability.

\section{REFERENCES}

Abdullah, M., Shahimi, S., \& Ghafar Ismail, A. (2011). Operational Risk in Islamic banks: Examination of Issues. Qualitative Research in Financial Markets. https:// doi.org/10.1108/17554171111155366

Abuzayed, B., Al-Fayoumi, N., \& Molyneux, P. (2018). Diversification and Bank Stability in the GCC. Journal of International Financial Markets, Institutions and Money. https://doi.org/10.1016/j.intfin.2018.04.005

Adjei-Frimpong, K., Gan, C., \& Hu, B. (2016). Competition in the Banking Industry: Empirical Evidence from Ghana. Journal of Banking Regulation, 17, 159-175. https://doi.org/10.1057/jbr.2014.24 
Agnes Isnawangsih, Klyuev, V., \& Longmei Zhang. (2013). The Big Split: Why Did Output Trajectories in the ASEAN-4 Diverge after the Global Financial Crisis? IMF.

Alaeddin, O., Khattak, M. A., \& Abojeib, M. (2019). Evaluating Stability in Dual Banking System : Comparison Between Conventional And Islamic Banks in Malaysia. Humanities E Social Sciences Reviews, 7, 510-518.

Albaity, M., Mallek, R. S., \& Noman, A. H. M. (2019). Competition and Bank Stability in the MENA region: The Moderating Effect of Islamic versus Conventional Banks. Emerging Markets Review. https://doi.org/10.1016/j.ememar.2019.01.003 Ali, M., Haroon, O., Rizvi, S. A. R., \& Azmi, W. (2020). Stability versus fragility: New Evidence from 84 Banks. Studies in Economics and Finance.

Ali, M., \& Khattak, M. A. (2020). Income Structure and Performance: an Empirical Analysis of Islamic and Conventional Banks in Indonesia. Buletin Ekonomi Moneter Dan Perbankan, 23, 87-108. https://doi.org/10.21098/bemp.v23i0.1193

Allen, F., \& Gale, D. (2004). Competition and Financial Stability. Journal of Money Credit Bank, 36, 453-480. https://doi.org/10.1353/mcb.2004.0038

Amidu, M., \& Wolfe, S. (2013). Does Bank Competition and Diversification Lead to Greater Stability? Evidence from Emerging Markets. Review of Development Finance, 3, 152-166. https://doi.org/10.1016/j.rdf.2013.08.002

Appiah-Otoo, I. (2020). Does COVID-19 Affect Domestic Credit? Aggregate and Bank Level Evidence From China. Asian Economics Letters, 1(3). https://doi. org/10.46557/001c.18074

Arellano, M., \& Bond, S. (1991). Some Tests of Specification for Panel Data: Monte Carlo Evidence and an Application to Employment Equations. The Review of Economic Studies, 58, 277. https://doi.org/10.2307/2297968

Arellano, M., \& Bover, O. (1995). Another Look at the Instrumental Variable Estimation of Error-Components Models. Journal of Econometrics, 68, 29-51. https://doi.org/10.1016/0304-4076(94)01642-D

Ariss, R. T. (2010). Competitive Conditions in Islamic and Conventional Banking: A Global Perspective. Review of Financial Economics, 19, 101-108. https://doi. org/10.1016/j.rfe.2010.03.002

Azmi, W., Ali, M., Arshad, S., \& Rizvi, S. A. R. (2019). Intricacies of Competition, Stability, and Diversification: Evidence from Dual Banking Economies. Economic Modelling. https://doi.org/10.1016/j.econmod.2019.02.002

Baele, L., De Jonghe, O., \& Vander Vennet, R. (2007). Does the Stock Market Value Bank Diversification? Journal of Banking and Finance, 31, 1999-2023. https://doi. org/10.1016/j.jbankfin.2006.08.003

Beccalli, E., Anolli, M., \& Borello, G. (2015). Are European banks too big? Evidence on economies of scale. Journal of Banking and Finance, 58(April), 232-246. https:// doi.org/10.1016/j.jbankfin.2015.04.014

Beck, T., De Jonghe, O., \& Schepens, G. (2013). Bank Competition and Stability: Cross-Country Heterogeneity. Journal of Financial Intermediation, 22, 218-244. https://doi.org/10.1016/j.jfi.2012.07.001

Beck, T., Demirgüç-Kunt, A., \& Merrouche, O. (2013). Islamic vs. Conventional Banking: Business Model, Efficiency and Stability. Journal of Banking and Finance, 37, 433-447. https://doi.org/10.1016/j.jbankfin.2012.09.016

Bikker, J. a, \& Haaf, K. (2002). Competition, Concentration and Their Relationship : an Empirical Analysis of the Banking Industry. Journal of Banking $\mathcal{E}$ Finance, 26, 2191-2214. https://doi.org/10.1016/S0378-4266(02)00205-4 
Blundell, R., \& Bond, S. (1998). Initial Conditions and Moment Restrictions in Dynamic Panel Data Models. Journal of Econometrics, 87, 115-143. https://doi. org/10.1016/S0304-4076(98)00009-8

Boateng, A., Asongu, S., Akamavi, R., \& Tchamyou, V. (2018). Information Asymmetry and Market Power in the African Banking Industry. Journal of Multinational Financial Management, 44, 69-83. https://doi.org/10.1016/j. mulfin.2017.11.002

Boyd, J. H., Nicolò, G. De, \& Jalal, A. (2006). Bank Risk-Taking and Competition Revisited: New theory and new evidence (Working Paper No. WP/06/297). IMF.

Čihák, M., \& Hesse, H. (2010). Islamic Banks and Financial Stability: An Empirical Analysis. Journal of Financial Services Research, 38, 95-113. https://doi. org/10.1007/s10693-010-0089-0

Demirgüç-Kunt, A., \& Detragiache, E. (2009). Basel Core Principles and Bank Soundness, Does Compliance Matter? (Policy Research Working Paper). World Bank.

Devpura, N. (2020). Can Oil Prices Predict Japanese Yen? Asian Economics Letters, 1. https://doi.org/10.46557/001c.17964

Devpura, N., \& Narayan, P.K., (2020) Hourly Oil Price Volatility: The Role of COVID-19, Energy Research Letters, 1, 13683. https://doi.org/10.46557/001c.13683

Deyoung, R., \& Roland, K. P. (2001). Product Mix and Earnings Volatility at Commercial Banks: Evidence from a Degree of Total Leverage Model. Journal of Financial Intermediation, 10. https://doi.org/10.1006/jfin.2000.0305

Fang, X., \& Zhang, Y. (2021). An Analysis of the Dynamic Asymmetric Impact of the COVID-19 Pandemic on the RMB Exchange Rate. Asian Economics Letters, 1. https://doi.org/10.46557/001c.18644

Fiordelisi, F., \& Mare, D. S. (2014). Competition and Financial Stability in European Cooperative Banks. Journal of International Money and Finance, 45, 1-16. https:// doi.org/10.1016/j.jimonfin.2014.02.008

Forssbæck, J., \& Tanveer, C. (2011). Competition and Bank Risk-Taking - An Empirical Study.

Froot, K. A., \& Stein, J. C. (1998). Risk Management, Capital Budgeting, and Capital Structure Policy for Financial Institutions: an Integrated Approach. Journal of Financial Economics, 47, 55-82.

Fu, X. (Maggie), Lin, Y. (Rebecca), \& Molyneux, P. (2014). Bank Competition and Financial Stability in Asia Pacific. Journal of Banking and Finance, 38, 64-77. https://doi.org/10.1016/j.jbankfin.2013.09.012

Fungáčová, Z., \& Weill, L. (2013). Does Competition Influence Bank Failures? Evidence from Russia. Economics of Transition, 21, 301-322. https://doi. org/10.1111/ecot.12013

Gil-Alana, L. A., \& Monge, M. (2020). Crude Oil Prices and COVID-19: Persistence of the Shock. Energy Research Letters, 1, 13200. https://doi.org/10.46557/001c.13200

Gil-Alana, L. A., \& Claudio-Quiroga, G. (2020). The COVID-19 Impact on the Asian Stock Markets. Asian Economics Letters, 1. https://doi.org/10.46557/001c.17656

Goddard, J., Molyneux, P., \& Wilson, J. O. S. (2009). The Financial Crisis in Europe: Evolution, Policy Responses and Lessons for the Future. Journal of Financial Regulation and Compliance. https://doi.org/10.1108/13581980911004352 
Goetz, M. R. (2017). Competition and Bank Stability. Journal of Financial Intermediation, 0, 1-13. https://doi.org/10.1016/j.jfi.2017.06.001

Hellmann, T. F., Murdock, K. C., \& Stiglitz, J. E. (2000). Liberalization, Moral Hazard in Banking, and Prudential Regulation: Are Capital Requirements Enough? American Economic Review. https://doi.org/10.1257/aer.90.1.147

Hoang, T. H. V., \& Syed, Q. R. (2021). Investor Sentiment and Volatility Prediction of Currencies and Commodities During the COVID-19 Pandemic. Asian Economics Letters, 1. https://doi.org/10.46557/001c.18642

Huang, W., \& Zheng, Y., (2020) COVID-19: Structural Changes in the Relationship Between Investor Sentiment and Crude Oil Futures Price. Energy Research Letters, 1, 13685. https://doi.org/10.46557/001c.13685

Ijtsma, P., Spierdijk, L., \& Shaffer, S. (2017). The Concentration-Stability Controversy in Banking: New Evidence from the EU-25. Journal of Financial Stability, 33, 273-284. https://doi.org/10.1016/j.jfs.2017.06.003

Iyke, B. N. (2017). Does Trade Openness Matter for Economic Growth in the CEE Countries?. Review of Economic Perspectives, 17, 3-24. https://doi.org/10.1515/ revecp-2017-0001

Iyke, B. N. (2020a). Economic Policy Uncertainty in Times of COVID-19 Pandemic. Asian Economics Letters, 1. https://doi.org/10.46557/001c.17665.

Iyke, B. N. (2020b). COVID-19: The Reaction of US Oil and Gas Producers to the Pandemic. Energy Research Letters, 1, 13912. https://doi.org/10.46557/001c.13912.

Iyke, B. N. \& Ho, S.-Y. (2021). Investor Attention on COVID-19 and African Stock Returns. MethodsX, 8, 101195. https://doi.org/10.1016/j.mex.2020.101195.

Jiménez, G., Lopez, J. A., \& Saurina, J. (2013). How Does Competition Affect Bank Risk-Taking? Journal of Financial Stability, 9, 185-195. https://doi.org/10.1016/j. jfs.2013.02.004

Juhro, S. M., \& Iyke, B. N. (2019). Monetary Policy and Financial Conditions in Indonesia. Buletin Ekonomi Moneter dan Perbankan, 21, 283-302.

Juhro, S. M., Narayan, P. K., Iyke, B. N., \& Trisnanto, B. (2020). Is There a Role for Islamic Finance and R\&D in Endogenous Growth Models in the Case of Indonesia?. Pacific-Basin Finance Journal, 62, 101297. https://doi.org/10.1016/j. pacfin.2020.101297

Kabir, M. N., \& Worthington, A. C. (2017). The 'Competition-Stability/Fragility' Nexus: A Comparative Analysis of Islamic and Conventional Banks. International Review of Financial Analysis, 50, 111-128. https://doi.org/10.1016/j. irfa.2017.02.006

Karakaya, A., \& Er, B. (2012). Noninterest (Nonprofit) Income and Financial Performance at Turkish Commercial and Participation Banks. International Business Research. https://doi.org/10.5539/ibr.v6n1p106

Keeley, M. C. (1990). Deposit Insurance, Risk, and Market Power in Banking. American Economic Review, 80, 1183-1200. https://doi.org/10.2307/2006769

Kouki, I., \& Al-Nasser, A. (2017). The Implication of Banking Competition: Evidence from African Countries. International Business and Finance, 39, 878895. https://doi.org/10.1016/j.ribaf.2014.09.009

Laeven, L., \& Levine, R. (2009). Bank Governance, Regulation and Risk Taking. Journal of Financial Economics, 93, 259-275. https://doi.org/10.1016/j. jfineco.2008.09.003 
Landskroner, Y., Ruthenberg, D., \& Zaken, D. (2005). Diversification and performance in Banking: The Israeli Case. Journal of Financial Services Research. https://doi.org/10.1007/s10693-005-6411-6

Leroy, A., \& Lucotte, Y. (2017). Is There a Competition-Stability Trade-Off in European Banking? Journal of International Financial Markets, Institutions and Money, 46, 199-215. https://doi.org/10.1016/j.intfin.2016.08.009

Liu, H., Molyneux, P., \& Nguyen, L. H. (2012). Competition and Risk in South East Asian Commercial Banking. Applied Economics, 44, 3627-3644. https://doi.org/ 10.1080/00036846.2011.579066

Mercieca, S., Schaeck, K., \& Wolfe, S. (2007). Small European Banks: Benefits from Diversification? Journal of Banking and Finance, 31, 1975-1998. https://doi. org/10.1016/j.jbankfin.2007.01.004

Mishkin, F. S. (1999). Financial Consolidation: Dangers and Opportunities. Journal of Banking and Finance, 23, 675-691. https://doi.org/10.1016/S03784266(98)00084-3

Narayan, P. K. (2020a). Oil Price News and COVID-19-Is There Any Connection?. Energy Research Letters, 1, 13176. https://doi.org/10.46557/001c.13176

Narayan, P. K. (2020b). Has COVID-19 Changed Exchange Rate Resistance to Shocks? Asian Economics Letters, 1. https://doi.org/10.46557/001c.17389

Narayan, P. K. (2020c). Did Bubble Activity Intensify During COVID-19? Asian Economics Letters, 1. https://doi.org/10.46557/001c.17654

Nguyen, M., Perera, S., \& Skully, M. (2016). Bank Market Power, Ownership, Regional Presence and Revenue Diversification: Evidence from Africa. Emerging Markets Review, 27, 36-62. https://doi.org/10.1016/j.ememar.2016.03.001

Nurul, K., \& Worthington, A. C. (2015). The 'Competition - Stability Nexus ': Is Efficiency an Appropriate Channel ? Griffith Business School Discussion Papers Finance, ISSN 1836-(February 2016). https://doi.org/10.13140/RG.2.1.1031.1443

Pawlowska, M. (2016). Does the Size And Market Structure of the Banking Sector Have an Effect on the Financial Stability of the European Union? Journal of Economic Asymmetries, 14, 112-127. https://doi.org/10.1016/j.jeca.2016.07.009

Pawłowska, M. (2015). On Competition in the Banking Sector in Poland and Europe Before and During the Crisis. In: Bank-Case Seminar Proceedings No. 134/2014.

Pennathur, A. K., Subrahmanyam, V., \& Vishwasrao, S. (2012). Income diversification and Risk: Does Ownership Matter? An Empirical Examination of Indian Banks. Journal of Banking and Finance, 36, 2203-2215. https:/doi. org/10.1016/j.jbankfin.2012.03.021

Phan, D. H. B., Iyke, B. N., Sharma, S. S., \& Affandi, Y. (2020). Economic Policy Uncertainty and Financial Stability-Is There a Relation?. Economic Modelling, 94, 1018-1029. https://doi.org/10.1016/j.econmod.2020.02.042

Phan, D.H.B., and Narayan, P.K., (2020) Country Responses and the Reaction of the Stock Market to COVID-19-a Preliminary Exposition. Emerging Markets Finance and Trade;56, 2138-2150; https://doi.org/10.1080/1540496X.2020.1784719.

Prabheesh, K.P., Padhan, R., \& Garg, B., (2020) COVID-19 and the Oil Price-Stock Market Nexus: Evidence from net Oil-Importing Countries. Energy Research Letters, 1, 13745. https://doi.org/10.46557/001c.13745

Rizvi, S. A. R., Narayan, P. K., Sakti, A., \& Syarifuddin, F. (2019). Role of Islamic banks in Indonesian Banking Industry: An Empirical Exploration. Pacific Basin Finance Journal, 101117. https://doi.org/10.1016/j.pacfin.2019.02.002 
Roodman, D. (2009a). A Note on the Theme of Too Many Instruments. Oxford Bulletin of Economics and Statistics. https://doi.org/10.1111/j.1468-0084.2008.00542.x

Roodman, D. (2009b). How to Do Xtabond2: An Introduction to Difference and System GMM in Stata. Stata Journal, 9, 86-136. https://doi.org/10.2139/ ssrn. 982943

Salisu, A., \& Adediran, I. (2020). Uncertainty Due to Infectious Diseases and Energy Market Volatility. Energy Research Letters, 1, 14185. https://doi. org/10.46557/001c.14185

Salisu, A. A., \& Sikiru, A. A. (2020). Pandemics and the Asia-Pacific Islamic Stocks. Asian Economics Letters, 1. https://doi.org/10.46557/001c.17413

Sanya, S., \& Wolfe, S. (2011). Ownership Structure, Revenue Diversification and Insolvency Risk in European Banks (March 1, 2011). https://papers.ssrn.com/ sol3/papers.cfm?abstract_id $1 / 41787476$.

Schaeck, K., \& Cihak, M. (2014). Competition, Efficiency, and Stability. Financial Management, 215-241. https://doi.org/https://doi.org/10.1111/fima.12010

Schaeck, K., Cihak, M., \& Wolfe, S. (2009). Are Competitive Banking Systems More Stable? Journal of Money, Credit and Banking, 41, 711-734. https://doi. org/10.1111/j.1538-4616.2009.00228.x

Sha, Y., \& Sharma, S.S., (2020) Research on Pandemics Special Issue. Journal Emerging Markets Finance and Trade, 56, 2133-2137; https://doi.org/10.1080/154 0496X.2020.1795467

Sharma, S.S., \& Sha, Y., (2020) Part A: Special Section on COVID-19 Research. Emerging Markets Finance and Trade, 56 , 3551-3553. https://doi.org/10.1080/154 0496X.2020.1858617

Sharma, S. S. (2020). A Note on the Asian Market Volatility During the COVID-19 Pandemic. Asian Economics Letters, 1. https://doi.org/10.46557/001c.17661

Stiglitz;, J. E., \& Weiss, A. (1981). Credit Rationing in Markets with Imperfect Information. The American Economic Review, 71,393-410. https://doi.org/10.1126/ science.151.3712.867-a

Stiroh, K. J., \& Rumble, A. (2006). The Dark Side of Diversification: The Case of US Financial Holding Companies. Journal of Banking and Finance, 30, 2131-2161. https://doi.org/10.1016/j.jbankfin.2005.04.030

Turk Ariss, R. (2010). On the Implications Of Market Power In Banking: Evidence From Developing Countries. Journal of Banking and Finance, 34, 765-775. https:// doi.org/10.1016/j.jbankfin.2009.09.004

Wahid, M. A., \& Dar, H. (2016). Stability of Islamic Versus Conventional Banks: A Malaysian Case. Jurnal Ekonomi Malaysia, 50, 111-132. https://doi.org/10.17576/ JEM-2016-5001-09

Wang, K.-H., \& Su, C.-W. (2021). Asymmetric Link Between COVID-19 and Fossil Energy Prices. Asian Economics Letters, 1. https://doi.org/10.46557/001c.18742

Yang, H., \& Deng, P. (2021). The Impact of COVID-19 and Government Intervention on Stock Markets of OECD Countries. Asian Economics Letters, 1(4). https://doi. org/10.46557/001c.18646

Zahra, S. F., Ascarya, A., \& Huda, N. (2018). Stability Measurement of Dual Banking System in Indonesia: Markov Switching Approach. Al-Iqtishad: Jurnal Ilmu Ekonomi Syariah, 10, 25-52. 
This page is intentionally left blank 